\title{
THE EFFECT OF SOVIET DECREEES IN AMERICAN COURTS
}

Lours ConNick.

For more than seven years Russia has been governed by rulers who have not been recognized by the United States. Full diplomatic recognition has, however, been extended to the so-called Soviet Regime in Russia, officially known as the Russian Socialist Federated Soviet Republic, by Great Britain, France, Italy, Germany, Austria, China, Denmark, Esthonia, Lithuania, Mexico, Turkey, Afghanistan, Finland, Latvia, Poland, Persia, Greece, Norway, Sweden, Hungary, Albania, Mongolia, Khiva, Bokhara and the Free City of Dantzig. The New York Court of Appeals, in speaking of this government in Wulfsohn v. Russian Republic," said, "We have an existing government sovereign within its own territories. There necessarily its jurisdiction is exclusive and absolute. It is susceptible of no limitation not imposed by itself. This is the result of its independence." In proceedings to naturalize Russian subjects the executive and judicial branches of our own government acknowledge the existence of "the present government of Russia" to the extent of requiring such applicants for citizenship to foreswear allegiance to "the present government of Russia." If, indeed, we speak in terms of fact, it cannot be denied that this government is exercising all the attributes of sovereignty in Russia to-day. Whatever may be thought of its acts, we cannot doubt its presence, dominion and power within the territories subject to its rule. People who live within these territories are governed by its laws, and their rights and obligations cannot be judged or determined within such territories by any other law.

Toward this government the United States has steadfastly pursued, and is still pursuing, a policy of diplomatic non-recognition. The wisdom of such a policy is not a legal question. It is a political question with which the courts are not concerned, and which is and must be conclusively determined by the policy of the executive expressed through the Department of State. Mr. Justice Scrutton, in Luther v. James Sagor \& $\mathrm{Co}_{0 .}{ }^{3}$ said, "The responsibility for recognition or non-recognition with the consequences of each rests on the political advisers of the sovereign and not on the judges." Hence the policy of our government being one of non-recognition, and there apparently being no immediate

${ }^{1}$ (1923) 234 N. Y. $372,375-6$, 138 N. E. $24,25,26$.

${ }^{2}$ Russian Government v. Lehigh Valley R. R. (1919, S. D. N. X.) 293 Fed. I33, I35.

[I92I, C. A.] 3 K. B. 532, 559.

[499]. 
prospect of change, it becomes important to consider the limitations which may, as the result of this policy, be imposed upon the judiciary in determining questions affected by Russian law.

Precise understanding of these limitations will become of increasing importance as time goes on. Notwithstanding difficulties resulting from a state of diplomatic isolation, normal intercourse between people living in Russia and people living in the United States is being slowly restored through the channels of trade and communication. Our exports to Russia during the first nine months of 1924 were $\$ 37,407,883$. Imports from Russia during the same period were $\$ 5,185,285$. A single American company, financed with Russian capital and engaged in this trade, chartered twenty-four vessels to carry full cargoes of cotton to a Russian port during this period. During the year ending June 30, I924, 24,405 aliens born in Russia were admitted to the United States under our immigration laws. It is to be assumed that such persons will continue to come to this country to the extent permitted by our laws. Such persons bring with them rights and obligations dependent upon and. growing out of their residence in Russia under Soviet rule, and it is of the utmost importance to know whether the laws of the Soviet can be regarded in determining their rights and obligations when they arise for determination in our courts. There are pending in our courts to-day actions brought by Russian corporations which it is claimed have been dissolved under Soviet decrees, and the important question which will be decided in these and other cases is to what extent and under what circumstances may an American court give effect to the laws of an unrecognized foreign government with which our government refuses to have diplomatic intercourse. The question was considered but not decided in Sokoloff v. National City Bank, , where it was said:

"Juridically a government that is unrecognized may be viewed as no government at all, if the power withholding recognition chooses thus to view it. In practice, however, since juridical conceptions are seldom, if ever, carried to the limit of their logic, the equivalence is not absolute. but is subject to self-imposed limitations of common sense and fairness, as we learned in litigations following our Civil War."

In determining what is law in foreign territory one must of necessity determine who is the sovereign. Under ordinary circumstances this inquiry is not open to the courts. In Jones $v$. United States ${ }^{5}$ it was held that "who is the sovereign, de jure or de facto, of a territory is not a judicial, but a political question, the determination of which by the legislative and executive departments of any government binds the judges as well as all other officers, citizens and subjects of that government."

The reason for the rule is clear, since the conduct of foreign affairs is committed by the constitution to the executive and legislative departments of the government, and the propriety of what may be done in the

( (1924) 239 N. Y. I58, 165, I45 N. E. 917, 918.

(I890) I37 U. S. 202, 212. 
exercise of this power cannot be made the subject of judicial inquiry or decision. ${ }^{6}$ These principles have been applied in many cases. ${ }^{7}$ And if the executive, in withholding recognition, can be said to have chosen to regard the regime now functioning in Russia as no government at all, such determination must certainly be conclusive upon the courts and deprive the Soviet decrees of any force whatsoever in determining the rights of private individuals in litigation before our courts. On the other hand, if the executive, in withholding recognition, has not chosen to so regard the present Russian Government, the question discussed but not decided in the Sokoloff case remains for future consideration and decision in the courts. Consequently it is necessary to determine whether the executive has chosen to regard the Soviet Regime as no government at all, or, while conceding its existence, has merely withheld recognition and refused to have diplomatic intercourse with it.

This question is fairly answered by the correspondence with Secretary of State Hughes quoted in the opinion of the court in Russian Government v. Lehigh Valley R.R., from which it appears that the State Department, while refusing to recognize the present Russian Government and continuing to have official intercourse for certain purposes with the diplomatic agents of the Provisional Government, does at the same time concede that the Provisional Government has ceased to exist and that the "Soviet Regime" is now functioning in Russia. It appears that under date of February I7, 1923, counsel for the defendant in this action addressed the following letter of inquiry to the Secretary of State:

Hon. Charles E. Hughes,

"February I7, I923.

Secretary of State,

Washington, D. C.

My dear Mr. Secretary:

I am asking my partner, Mr. Raoul E. Desvernine, to present this letter and secure, if he can, such answers as you deem proper to make to the following questions:

(I) What is the present government of Russia, and its name?

(2) Has such government been recognized by the United States?

(3) What is the extent and nature of such recognition?

- Oetjen v. Central Leather Co. (I9I8) 246 U. S. 297, 302, 38 Sup. Ct. 309, 3Ir.

'United States v. Palmer (1818, U. S.) 3 Wheat. 610; Foster v. Nielson (1829, U. S.) 2 Pet. 253, 307, 309; Garcia v. Lee (I838, U. S.) I2 Pet. 5II; Williams v. Suffolk Insurance Co. (I839, U. S.) I3 Pet. 415, 420; In re Cooper (I892) r43 U. S. 472, 499, I2 Sup. Ct. 453, 459; Luther v. Borden (1849, U. S.) 7 How. I; Rose v. Himely (I808, U. S.) 4 Cranch, 24I, 272; Kennett v. Chambers (1852, U. S.) I4 How. 38 ; Gelston v. Hoyt (1818, U. S.) 3 Wheat. 246, 324; The Nueva Anna (I821, U. S.) 6 Wheat. 193; The Three Friend's (I897) I66 U. S. I, I7 Sup. Ct. 495 .

'Supra note 2; (motion for leave to file petition for writ of prohibition and / or writ of mandamus denied (I924) 265 U. S. 573, 44 Sup. Ct. 460). 
If, through ignorance of the proper procedure, I have not asked the appropriate questions, what I am after is to ascertain whether there is any government in Russia to-day which the United States government has recognized. My reason for asking these questions is that I am defending a case brought by the Russian government against the Lehigh Valley Railroad Company, which is set for trial on Tuesday, and I understand that for the solution of questions of this kind the courts look to the Department of State for information.

Sincerely yours,

LindeEy M. GarRison."

On February Igth, I923, the Secretary of State, replying to this inquiry, wrote:

"Department of State, Washington, February I9, I923.

\section{My Dear Judge Garrison:}

In reply to the inquiry contained in your letter of February I7, I923, and to certain additional inquiries made orally to-day by your partner, Mr. Raoul E. Desvernine, I have to inform you that the so-called provisional government of Russia, which succeeded to authority upon the abdication of the Czar, was recognized by the government of the United States on March 22, I9I7. On July 5 of the same year Mr. Boris Bakhmetieff was received by the President as the ambassador extraordinary and plenipotentiary of the newly recognized government.

Mr. Bakhmetieff continued to be recognized as the ambassador of Russia to the United States until June 30, I922. The custody of the property of the Russian government in this country, for which $\mathrm{Mr}$. Bakhmetieff had been responsible, was, after the date of his retirement, considered to vest in Mr. Serge Ughet, the financial attache of the Russian embassy, whose diplomatic status with this government was not considered to be altered by the termination of the ambassador's duties.

In answer specifically to your questions, I may say that the United States has not recognized any other government in Russia since the fall of the provisional government, to which reference is made above.

The regime now functioning in Russia, and known as the "Soviet Regime,' has not been recognized by the United States.

\section{Sincerely yours,}

Charles E. Hughes.

Hon. Lindley M. Garrison,

No. 24 Broad Street,

New York City."

It is important to note that the Secretary refers to the "fall of the provisional government," which, as a matter of public knowledge, occurred through the expulsion or imprisonment of its ministers early in November, I9I7, and was consummated by the forcible dispersement of the constituent assembly on December I $3^{\text {th }}$, I9I7. The Secretary further states that the United States has not recognized any other gov- 
ernment in Russia since the fall of the Provisional Government, and states specifically that the United States has not recognized "the regime now functioning in Russia, and known as the 'Soviet Regime." From these statements it is apparent that the executive has not chosen to regard the present regime in Russia as no government at all. The absurd and impossible conclusion that during a period of over seven years Russia has been totally devoid of law, is not to be lightly imputed to the responsible officers of our government.

It may perhaps be thought that the continued reception of the diplomatic agents of the Provisional Government is necessarily a determination by our own government that no goverment has existed in Russia since the fall of the Provisional Government, and in this connection not only the correspondence above quoted but the decision in Russian Government $v$. Lehigh Valley R.R. ${ }^{9}$ may be referred to, where it was held that an action commenced by the accredited ambassador of the Provisional Russian Government after the fall of that government was properly commenced, and could be maintained and continued by one of his subordinates whose diplomatic status was not considered by the executive to have been altered, and in whom our government considered that the custody of the property of the Russian Government in this country had been vested. (See correspondence heretofore quoted.) The theory of the decision was not that the Provisional Russian Government continues to function in Russia, but that the real party in interest was the State of Russia, and that Russia, the state, still lives, and is a continuing entity in contemplation of law. The court said:

"The question suggesting itself is: how can Mr. Ughet represent a government which has fallen? The answer is that the provisional government had fallen when $\mathrm{Mr}$. Bakhmetieff began the suits, and they are held to have been properly begun, for the reason that at the time our government recognized him as such ambassador, and the court is bound by the action of our government, and so, regardless as to whether or not that government may have fallen, if our government considers this 'financial attache of the Russian embassy, whose diplomatic status with this government was not considered to be altered,' to have become vested with the custody of the property of the Russian government after Mr. Bakhmetieff's retirement, I think that it is conclusive with the court, and that in this capacity the plaintiff may prosecute these suits. No precedent for such a situation has been presented to me, and I have not been able to find one. I feel, however, that our government may have adopted this plan for the purpose of preventing what otherwise would have been a loss of rights to Russia, because of its refusal to recognize the present regime now functioning in Russia, and I come more readily to the conclusion that I do, for I realize how highly important it is that the rights of Russia shall not be lost in this manner."

It is clear that the state must be distinguished from its government. The existence of the state as a nation is regarded as continuous, no mat-

- Supra note 2. 
ter what revolutionary changes may occur in its government. Revolution does not destroy the state, although it may disrupt and destroy its government. ${ }^{10}$ If, in the course of revolution, the old regime is utterly destroyed, nevertheless until the new regime is recognized the diplomatic representatives accredited by the old regime may continue at their posts in foreign countries as representatives, not of the government which has ceased to exist, but of the state, which continues to exist regardless of revolutionary change.

The history of our government's dealings with Ambassador Bakhmetieff and his recognized successor as custodian of Russian government property, Mr. Serge Ughet, discloses to what limits this fiction has been carried. Senate Document No. 86, 67th Congress, Second Session, contains a record of these transactions, from which it appears that after the fall of the Provisional Government Mr. Bakhmetieff, in his capacity as Russian Ambassador, and Mr. Ughet, the Financial Attache of the Russian Embassy, received from the Navy Department moneys payable to the Russian State for charter hire, and entered into a contract in the name of the Russian Government with the War Department for the purchase of war supplies and munitions, depositing one million dollars worth of gold shipped from Vladivostok on a United States army transport as security to guarantee payment by the Russian Government under this contract. When, by reason of the fall of the Kolchak Government, this contract could not be performed, a portion of the gold was paid to the War Department and the balance" to the National City Bank "for Russian Government."

In a memorandum of a conference between $\mathrm{Mr}$. Ughet and a representative of our State Department appearing in this document, at page 173, the following appears:

"Mr. Ughet pointed out that before the dissolution of the Kolchak government he had been authorized by that government to dispose of funds for purposes helpful to Denekin or Wrangel in South Russia. I explained to him that we doubted whether such authorization would protect him now that his former principal, the Kolchak government, had dissolved.

I brought up the question of the million dollars held as security by the War Department. I notified him that we considered that $(x)$ these were funds brought officially to the notice of the Government on account of their having been held by the Government, that (2) the contract was made in behalf of the Russian Government, and (3) the situation had now changed and his formerly existing principal, the Kolchak government, which we had approved, had now dissolved. For these reasons we felt that the sum should be either held by the War Department or deposited in the liquidation account. This was accepted without any protest on his part."

Payments were also made by the Shipping Board to Mr. Bakhmetieff through Mr. Ughet of sums due to the Russian Government for charter

\footnotetext{
${ }^{10}$ The Sapphire (I870, U. S.) II Wall. 164.
} 
hire of Russian ships. It is not necessary to detail these transactions more fully. They are set out in the document referred to, which was printed December 6, I92I, and which discloses that our government consistently dealt with Mr. Bakhmetieff, not as the representative of the Provisional Government, which had ceased to exist, but as the accredited diplomatic representative of the Russian state or nation as distinguished from any government existing or theretofore existing.

Until there is some definite determination by the executive that the Soviet Government is to be regarded as no government at all, it seems clear that neither its non-recognition nor the continuance of the authority of the diplomatic agents of the Provisional Government precludes the courts from considering that the Soviet Government is in fact a government ruling by paramount force. ${ }^{11}$

What effect, then, may the courts give to the laws of a foreign government which has not been recognized by the executive, but which, as a matter of common knowledge, is ruling through the exercise of paramount force? The question is not novel, and has been dealt with in a number of decisions of the Supreme Court, one of the latest of which is found in MacLeod v. United States. ${ }^{12}$. In that case the plaintiff, on January 29, I899, imported into the Island of Cebu, in the Philippine Islands, a cargo of rice, upon which he was required to pay duties to the native government, the native inhabitants, formerly in insurrection against Spain, having taken complete possession of the Island in December, I898, formed a so-called republic, and administered the affairs of the Island until possession was surrendered to the United States on February 22, I899. Thereafter the plaintiff was required by the Collector of Customs at Manila to pay duties upon the same cargo to the United States, and suit was brought in the Court of Claims to recover. the amount of this payment. Although the native government had never in any way been recognized by the United States, the Supreme Court held that this government was of the class of de facto governments described in Thorington $v$. Smith ${ }^{13}$ as follows:

"But there is another description of government, called also by publicists a government de facto, but which might, perhaps, be more aptly denominated a government of paramount force. Its distinguishing

${ }^{11}$ Certain cases have arisen out of the Russian situation dealing with governmental rights or diplomatic representation which are not pertinent to this question. It has been held that the Russian Socialist Federated Soviet Republic cannot maintain an action in our courts. Russian Socialist Federated Soviet Republic v. Cibrario (I923) 235 N. Y. 255, I39 N. E. 259; The Penza (1921, E. D. N. Y.) 277 Fed. 91. Nor can an unrecognized government be sued as a defendant. Wulfsohn v. Russian Republic, supra note I; Nankivel v. Omsk All Russian Government (1923) 237 N. Y. 150, 142 N. E. 569.

${ }^{13}$ (1913) 229 U. S. 416, 33 Sup. Ct. 955.

${ }^{18}$ (1868, U. S.) 8 Wall. I, 9; see e.g. Comments (I922) 3i Yale LaW Journal, 534 
charcteristics are (I), that its existence is maintained by active military power, within the territories, and against the rightful authority of an established and lawful government; and (2), that while it exists, it must necessarily be obeyed in civil matters by private citizens who, by acts of obedience, rendered in submission to such force, do not become responsible, as wrongdoers, for those acts, though not warranted by the laws of the rightful government. Actual governments of this sort are established over districts differing greatly in extent and conditions. They are usually administered directly by military authority, but they may be administered, also, by civil authority, supported more or less directly by military force."

It was held that the tariff duties upon the cargo of rice were paid to the de facto authorities at Cebu, and the payment made to the United States at Manila was not a tariff duty, but an illegal and an unwarranted exaction in the nature of a penalty. While the case turned upon the construction of orders of the President, the court clearly recognized that the assessment of duties by the native government imposed upon the plaintiff not only the necessity, but the duty of payment because the native government was clearly entitled at least to the status of "a government of paramount force." In this decision reliance was placed upon the Mazatlan case and the Bluefields case, accounts of which appear in I Moore, International Law Digest (1906) 49 et seq. In the latter case the then Secretary of State, Mr. Fish, in his instructions to our Minister to Mexico regarding the exaction of duties previously paid to insurgents, said:

"The obligation of obedience to a government in a particular place in a country may be regarded as suspended, at least, when its authority is usurped, and is due to the usurpers if they choose to exercise it."

Perhaps of even more pertinence is the ruling of the Supreme Court in United States v. Rice. ${ }^{14}$ During the war of $18 \mathrm{I} 2$ the port of Castine, Maine, was occupied by the British forces, under whose rule the British Government exercised full civil and military authority over the inhabitants, establishing custom houses and collecting duties on imports. After the re-establishment of the American Government in Castine the Collector of Customs claimed the right to collect duties upon imports for which duties had already been paid to the British authorities during the period of their occupation. In commenting upon the situation Mr. Justice Story, writing the opinion of the court, said: $:^{15}$

"By the conquest and military occupation of Castine, the enemy acquired that firm possession which enabled him to exercise the fullest rights of sovereignty over that place. The sovereignty of the United States over the territory was, of course, suspended, and the laws of the United States could no longer be rightfully enforced there, or be obligatory upon the inhabitants who remained, and submitted to the conquerors.

1s (I8Ig, U. S.) 4 Wheat. 246.

15 Ibid. at p. 254. 
By the surrender the inhabitants passed under a temporary allegiance to the British Government, and were bound by such laws, and such only, as it chose to recognize and impose. From the nature of the case, no other laws could be obligatory upon them, for where there is no protection or allegiance or sovereignty, there can be no claim to obedience."

In speaking of the Confederate Government in the case of Thorington v. Smith ${ }^{16}$ the Supreme Court said that although this government was never recognized by the United States as a de facto government, its status was such as to make obedience to its authority in civil and local matters not only a necessity, but a duty, and that without such obedience civil order was impossible.

Mr. Warren, in his history of the Supreme Court, speaking of the litigation before the Supreme Court involving the status of the Confederacy, says $:^{17}$

"The legal status of the Confederate States and of their legislation during the war was settled by the Court as early as 1870 , in Hickman v. Jones, 9 Wall. I97, in which it held the Confederate Government to be 'simply an armed resistance to the rightful authority of the sovereign'; and all its acts were held invalid so far as they were in aid of the rebellion. While the more radical Republican leaders were insistent that all legislation of every kind enacted by the various States of the Confederacy were illegal and void, the Court took a more conservative and rational view; and in Horn v. Lockhart, I7 Wall. 570, in 1873 , it decided that the acts of the several Confederate States 'so far as they did not impair or tend to impair the supremacy of the National authority or the just rights of citizens under the Constitution, are, in general, to be treated as valid and binding. The existence of a state of insurrection and war did not loosen the bonds of society or do away with civil government." "

In a number of cases the courts recognized the validity of certain acts of the several states of the Confederacy or of their officers or under their authority. ${ }^{18}$ On the other hand, the courts refused to give any legal effect to the acts of the Confederacy which were in aid of the rebellion. ${ }^{19}$

\footnotetext{
${ }^{16}$ Supra note I3.

${ }^{17} 3$ Warren, The Supreme Court in United States History (1922) 139.

${ }^{18}$ Thorington $v$. Smith, supra note 13 ; United States v. Insurance Companies (1874, U. S.) 22 Wall. 99; Keith v. Clark (1874) 97 U. S. 454; United States v. Thomas (I872, U. S.) I5 Wall. 337; Baldy v. Hunter (1898) I7I U. S. 388; Snodgrass v. Adams (1874) $26 \mathrm{La}$. Ann. 235 ; Lay v. O’Neil (1877) 29 La. Ann. 722 ; Sharkey v. Bankston (1878) 3a La. Ann. 89x; Hill v. Boyland (1866) 40 Miss. 6I8; Lervis v. Hearne (I87I) 34 'Tex. 382; Hubbard Co. v. Harnden Express Co. (I872) Io R. I. 244; Dillard v. Alexander (1872, Tenn.) 9 Heisk. 719.

${ }^{20}$ Horn v. Lockhart (1873, U. S.) 17 Wall. 570; Williams v. Bruffy (1877) 96 U. S. I76; Lamar v. Micou (1884) II2 U. S. 452; Sprott v. United States (I874, U. S.) 20 Wall. 459; Texas v. White (1868, U. S.) 7 Wall. 700; Hickman v. Jones? (1869, U. S.) 9 Wall. I97; Hanawer v. Doane (I870, U. S.) I2
} 
Certainly if the laws of a government of paramount force formed in open rebellion against the government of the United States are entitled to be treated as valid and binding in our courts in the determination of private and civil rights, there can be no reason for refusing under similar circumstances to enforce the decrees of the Soviet Government. In the Sokoloff case, supra, the court said in referring to the cases dealing with the laws of the Confederacy:

"In those litigations acts or decrees of the rebellious governments, which, of course, had not been recognized as governments de facto, were held to be nullities when they worked injustice to citizens of the Union or were in conflict with its public policy. On the other hand, acts or decrees that were just in operation and consistent with public policy, were sustained not infrequently to the same extent as if the governments were lawful. These analogies suggest the thought that, subject to like restrictions, effect may at times be due to the ordinances of foreign governments which, though formally unrecognized, have notoriously an existence as governments de facto. Consequences appropriate enough when recognition is withheld on the ground that rival factions are still contending for the mastery, may be in need of readjustment before they can be fitted to the practice, now a growing one, of withholding recognition whenever it is thought that a government, functioning unhampered, is unworthy of a place in the society of nations. Limitations upon the general rule may be appropriate for the protection of one who has been the victim of spoliation, though they would be refused to the spoliator or to others claiming under him. We leave these questions open. At the utmost, they suggest the possibility that a body or group which has vindicated by the course of events its pretentions to sovereign power, but which has forfeited by its conduct the privileges or immunities of sovereignty, may gain for its acts and decrees a validity quasi-governmental, if violence to fundamental principles of justice or to our own public policy might otherwise be done."

These suggestions of the Court of Appeals are directly in conflict with the opinions of the Appellate Division of the Supreme Court of New York in the First Department. ${ }^{20}$

In these cases it was claimed that the plaintiff or defendant corporations organized under Russian law had been dissolved by Soviet decree. In the James case, on the second appeal the court said:21

"The various 'Decrees of Peoples Commissaries' issued by the Soviet regime have been held to be of no force in this jurisdiction because

Wall. 342; Legal Tender Cases, Knox v. Lee (I87o; U. S.) I2 Wall. 457; Hanauer v. Woodruff (1872, U. S.) 15 Wall. 439; Cornett v. Williams (1873, U. S.) 20 Wall. 226; Dezering v. Perdicaries (1877) 96 U. S. I93.

${ }^{20}$ James \& Co. v. Second Russian Ins. Co. (I924, Ist Dept.) 208 App. Div. I 4 I, 203 N. Y. Supp. 232; s. c. (1924) 210 App. Div. 82, 205 N. Y. Supp. 472; Joint Stock Co. of Volgakama O. \& C. Factory v. National City Bank (1924, App. Div. Ist Dept.) 206 N. Y. Supp. 476.

$=12$ 10 App. Div. at p. 83, 205 N. Y. Supp. at p. 473. 
of the non-recognition, by our federal authorities who carry on our diplomatic intercourse, of the ruling body in Russia promulgating these decrees."

The same court, in an opinion by the same judge in the Volgakama case, supra, said :22

"The affidavit supporting plaintiff's application shows that no Russian government has exercised any function in Russia since November, I9I7, except the Russian Socialist Federated Soviet Republic. Indeed, as a historical fact the court may take judicial notice of this event even in the absence of actual proof. The allegations then in effect are that the corporate existence of the plaintiff was terminated by some act or decree of the present unrecognized Soviet government of Russia. ***

But though competent proof were made which definitely established the fact that the corporate existence of the plaintiff was terminated by any act or decree of the Soviet government of Russia, such proof would not be considered by the courts in this country, as has been often latterly decided in New York tribunals and in federal judicatories."

The James case, ${ }^{23}$ second appeal, has been affirmed by the Court of Appeals ${ }^{24}$ but the refusal of the court to give effect to the Soviet decrees of dissolution was not, as in the Appellate Division, based simply upon "the non-recognition, by our Federal authorities who carry on our diplomatic intercourse, of the ruling body in Russia promulgating these decrees." The court decided that neither the national public policy nor any consideration of justice and equity required it to hold the defendant not amenable to the process of our courts. ${ }^{25}$ In the opinion of the court by Judge Cardozo it was said:

"We do not say that a government unrecognized by ours will always be viewed as non-existent by our courts though the sole question at issue has to do with a transaction between the unrecognized government and a citizen or subject of a government by which recognition has been given."

Under the precedents to which reference has certainly been made nonrecognition has certainly not been heretofore regarded as a sufficient reason for regarding as utterly void and of no legal effect the laws of an unrecognized government ruling by paramount force such as the Soviet regime in Russia is conceded to be.

$2206 \mathrm{~N}$. Y. Supp. at p. 480 .

${ }^{23}$ Supra note $2 \mathrm{I}$.

${ }^{24}$ N. Y. Ct. of Appeals (Jan. 2r, I925).

${ }^{25}$ The Appellate Division of the Supreme Court of New York in the Third Department in the case of Russian Reinsurance Company v. Stoddard (1925) 2Ir App. Div. 132, decided that the Soviet decrees of dissolution had not destroyed the right of the plaintiff corporation organized under Russian law to sue in our courts, stating in its opinion that neither necessity nor justice required the court to deny the plaintiff the right to sue. 
The true rule is undoubtedly stated in the dictum of Judge Cardozo in the Sokoloff case supra. Surely there can be no reason or justice in refusing to give any validity whatsoever to those laws of Russia upon which questions of purely private right and obligation must of necessity depend, provided that the courts do not, in so doing, undertake to reverse the determinations actually made by the executive in declaring the foreign policies of this government. The refusal of diplomatic intercourse for reasons of state policy in the nature of things does not touch the question of private right dependent upon the internal operations of Russian law. If recognition of foreign governments actually exercising sovereign powers is to be withheld long after all other authorities have been driven out, as in the case of Russia, the laws of the new regime, in so far as they have in fact operated in the creation of strictly private rights and obligations, must of necessity be given effect if those rights and obligations are to be determined in our courts. To close our courts to the determination of such questions or to require our judges to determine these rights and obligations according to the laws of the old regime; which in fact did not function in their creation, leads to the denial or distortion of private rights absurdly incompatible with the ends of justice. It is to be hoped that the courts, in dealing with this question, will follow the rule stated in the dictum of Judge Cardozo in the Sokoloff case supra, and the well-considered decisions of the Supreme Court dealing with the laws of the Confederacy. ${ }^{26}$

${ }^{28}$ See (I925) 34 YaIE LAw JournaL, 328. 